\section{Testing the Establishment of Eight Forbs in Mowed Lawns of Hard Fescue (Festuca brevipila) for Use in Pollinator Conservation}

\author{
Ian G. Lane \\ Department of Entomology, University of Minnesota, 1980 Folwell Avenue, \\ Hodson Hall, Room 219, Saint Paul, MN 55108
}

James Wolfin

Department of Entomology, University of Minnesota, 1980 Folwell Avenue, Hodson Hall, Room 219, Saint Paul, MN 55108

Eric Watkins

Department of Horticulture, University of Minnesota 1970 Folwell Avenue, Alderman Hall, Room 338, Saint Paul, MN 55108

\author{
Marla Spivak \\ Department of Entomology, University of Minnesota, 1980 Folwell Avenue, \\ Hodson Hall, Room 219, Saint Paul, MN 55108
}

Additional index words. bee lawn, flowering lawn, reconciliation ecology, urban diversity

\begin{abstract}
Public concern for the conservation of pollinating insect communities, such as bees, has created demand for more florally diverse landscapes. In urban environments, lawns form a large portion of cultivated land, and are typically managed to exclude flowering species richness. In this study, we investigated the establishment of eight flowering plants with pollinator value (plants that provide floral nectar and pollen for visiting insects) when coseeded with the turfgrass hard fescue (Festuca brevipila Tracey). The study was established as a dormant seeding at two locations in central Minnesota with substantially different soil types. Plots were maintained at either a 6- or 9-cm mowing height. We monitored these plantings over the 2014, 2015, and 2016 growing seasons for vegetative establishment and flowering of planted forbs. Of the eight forbs tested, Trifolium repens L., Prunella vulgaris ssp. lanceolata (W. Bartram) Hultén, Thymus serpyllum auct. non L., and Astragalus crassicarpus Nutt. established in at least one location. Mowing height did not affect vegetative establishment, but had a negative effect on the number of blooms produced by $P$. vulgaris ssp. lanceolata. Vegetative establishment was affected by location, with $P$. vulgaris ssp. lanceolata establishing in higher abundance in the moist loamy site, whereas $T$. serpyllum and $A$. crassicarpus established in higher abundance at the dry sandy site. This study represents an important first step in identifying appropriate plants and management practices for improving lawns as a resource for pollinators.
\end{abstract}

Pollination is an important ecosystem service valuable to both agriculture (Losey and Vaughan, 2006; Rader et al., 2015; Southwick and Southwick, 1992) and natural systems (Grubb, 1977; Ollerton et al., 2011). One group of pollinators, bees (Hymenoptera: Anthophila), has been of particular concern due to rapid declines of many species over the past 40 years (Goulson et al., 2015).

Received for publication 8 July 2019. Accepted for publication 22 Sept. 2019.

This work was conducted with support from the Environmental and Natural Resources Trust Fund administrated by the Legislative Commission on Minnesota Resources. We thank Andrew Hollman and Craig Krueger for their assistance in site preparation, establishment, and maintenance. We also thank Garett Heineck, Jason Ostergaard, and Jonathon Tetlie for their assistance in data collection. I.G.L. is the corresponding author. E-mail: lanex173@ umn.edu.

2150 use of land, having quadrupled in cover since 1945 (Bigelow and Borchers, 2017). The challenges and opportunities of conserving nature in urban habitats have been well reviewed (Goddard et al., 2010; McKinney, 2002), and will become increasingly important as $68 \%$ of the world's population is projected to live in cities by 2050 (United Nations, 2018). Turf lawns are one of the dominant green spaces in urban areas and are estimated to cover $\approx 1.9 \%$ of the continental United States, predominately in urbanized areas (Milesi et al., 2005). Lawns are managed as monocultures or mixtures of turfgrass species, but can host a variety of flowering forbs and grasses that are often considered weeds. In the United States, these plants are predominantly of European origin (Lerman and Milam, 2016; Wheeler et al., 2017; Whitney, 1985).

With lawns dominating a large portion of urban landscapes and only likely to increase, they are a natural target for measures to improve biodiversity. In Paris, France, gardening practices have been designed and incentivized to increase biodiversity through a program known as the "differential management" program (Shwartz et al., 2013). This program aims to modify a number of common landscaping practices, such as decreasing the frequency of mowing and amount of pesticide use. An evaluation of the program found that gardens certified as "biodiversity friendly" housed a greater diversity of pollinators, birds, butterflies, and wild plants. Lawns in the differential management program housed $69 \%$ of wild flowering plants, demonstrating lawns can be significant sources of diversity in this urban system. Researchers in Reading, United Kingdom, developed floral lawns with no grass component that hosted high abundances of flower-visiting insects compared with regular turf (Smith et al., 2014).

Although redesigning lawns to support biodiversity in Europe has met with some success, one key way they differ from North American lawns is that most forbs in European lawns are considered native to the region: between $83 \%$ and $94 \%$ (Bertoncini et al., 2012; Thompson et al., 2004). In contrast, in North American lawns, only a minority of flowering species are native [Lerman and Milam (2016) report 30\% of forbs found in lawns as native] and tend to be dominated by European species (Wheeler et al., 2017; Whitney, 1985), although this varies depending on location, climate, and management. European lawn flowers, such as white clover (Trifolium repens), attract a variety of insect visitors in U.S. landscapes (Larson et al., 2014), but native plants have been found to attract greater quantities and, in some cases, greater numbers of species than non-native flowers (Frankie et al., 2005; Pardee and Philpott, 2014; Smith et al., 2014), and strategies for increasing their presence in lawns would likely increase their ability to support biodiversity in North America. This is also a key challenge, as most North American native plants do not share the long pastoral history of Western Europe that likely shaped the evolution of these 
plants to tolerate repeated defoliation (Leffel and Gibson, 1973).

Repeated defoliation, in the form of mowing, seems to frequently impact the floral diversity of lawns, but in mixed ways. For lawns in Paris, there was no effect of mowing frequency on floral diversity, but higher mowing heights benefited floral richness in smaller home lawns, although not in large park lawns (Shwartz et al., 2013). In both the turfless floral lawns and conventional turf in Reading, United Kingdom, more intense mowing frequencies negatively impacted floral visitors, but floral richness was favored by intermediate mowing frequencies (Smith and Fellowes, 2014) where lawns were mowed to $4 \mathrm{~cm}$ when they attained $6 \mathrm{~cm}$ in height. One observational study in Paris found that mowing frequency, among other factors, negatively impacted plant diversity (Bertoncini et al., 2012). Conversely, another observational study of lawns in Sheffield, England, found that mowing frequency had little effect on plant richness (Thompson et al., 2004). In Saltdean, England, where mowing frequencies were experimentally controlled, an increase in both floral abundance and floral visitor abundance was observed under less intense mowing regimens (Garbuzov et al., 2014). In the United States, less frequent mowing was found to improve both floral resources and pollinator abundance and richness in suburban areas (Lerman et al., 2018). It seems clear that any effort to enhance lawns for biodiversity must consider how mowing affects the establishment and maintenance of forbs within lawns.

To increase the ability of lawns to support biodiversity in North America, we set out with the objective of identifying forb species and mowing practices that could be used during the establishment of a new lawn to achieve greater floral diversity and abundance. We targeted six native forbs with low growth habits and seed availability from commercial sources, and two non-native species that were commercially available, have a known value to bees, and are relatively noninvasive in natural areas. We tested if 1) interseeding these forbs at time of lawn establishment would result in establishment and bloom of target forbs, and 2) if mowing height would affect the ability of target forbs to establish and bloom in these same lawn plantings. Because native plants with low growing habits come from a variety of both moist and dry habitats, we chose two different locations for our study with different soil environments. One location was a "xeric site," with a well-drained sandy soil with limited organic matter, and the other a "mesic site" with loamy soil and high organic matter. We predicted that study locations would favor different species, and that higher mowing heights would generally aid the establishment and bloom of targeted forbs in both locations.

\section{Materials and Methods}

Site characteristics. Two study sites were established by dormant seeding in November of 2013 (late fall in Minnesota): one at the Turfgrass Research Outreach and Education Center (TROE) at the University of Minnesota St. Paul campus and the other at the University of Minnesota Sand Plains Research Farm (SPRF) located in Becker, MN. Both soil types are commonly found in the seven-county metro area of MinneapolisSaint Paul. Aggregate soil samples were taken over the entire study area at each site. The TROE site was a silty clay loam $(7.5 \%$ sand, $61.3 \%$ silt, $31.3 \%$ clay) with an organic matter content of $4.3 \%$ (Supplemental Table 1), with a soil profile designation of Kingsley sandy loam with a $2 \%$ to $6 \%$ slope. The SPRF site was a sandy clay loam $(68.8 \%$ sand, $8.2 \%$ silt, and $22.5 \%$ clay) with an organic matter content of $1.7 \%$ (Supplemental Table 1) and a soil profile designation of Hubbard-Mosford complex with $0 \%$ to $3 \%$ slope. Sites were prepared for planting through an application of glyphosate, rototilling, and soil leveling to create an adequate soil bed.

Site climatic conditions varied slightly between sites during the April to September growing season. The TROE location averaged slightly higher monthly temperatures in 2014 through 2016 (Supplemental Table 2), being on average $0.9{ }^{\circ} \mathrm{C}$ warmer than the SPRF. Average monthly precipitation was higher at the SPRF in 2014 and 2015, averaging $2.1 \mathrm{~cm}$ and $1.1 \mathrm{~cm}$ more rain fall than TROE, respectively, but was higher at TROE in 2016 with an average of $3 \mathrm{~cm}$ more rain fall than the SPRF (Supplemental Table 2).

Species selection. Eight forb species were selected (Table 1) for coestablishment with turfgrass based on recommendations from local nursery growers, growth height characteristics, and perceived value as a forage plant for bees; that is, a flower that provides floral nectar or pollen for bee pollinators. Hard fescue (Festuca brevipila) was chosen as the companion turf species for its slow growth habit and low water and fertilizer input needs along with results from an earlier study showing its utility in a flowering lawn (Lane et al., 2019). Forb seed lots for each species were tested for germination in 2015 (Supplemental Table 3).

Site establishment. Dormant seeding was used due to multiple flower species having a cold stratification requirement for germination. Seeding of experimental plots occurred in November of 2013, and proceeded as follows: a broadcast seeding hard fescue at a rate of $171 \mathrm{~kg} \cdot \mathrm{ha}^{-1} \mathrm{~N}$ over the 0.26 -ha area that all single-species forb plots would be seeded, then forb species were hand seeded into meter-square monospecies plots at a standardized rate of 241 seeds per plot. Surface seeding was chosen as our establishment method, as it is the most commonly used method for seeding new lawns. Monospecies plots were arranged in a randomized complete block design with five replicates, and two blocks of species per replicate. Each species block within a replicate was assigned either a low mowing height or a high mowing height treatment. This resulted in a total of 80 monospecies plots, with each species being replicated five times in the low mowing height and high mowing height treatment at both locations.

At time of seeding, a starter fertilizer application of Sustane $(4 \mathrm{~N}-1.76 \mathrm{P}-3.32 \mathrm{~K})$ was applied at the rate of $21 \mathrm{~kg} \cdot \mathrm{ha}^{-1} \mathrm{P}(47.7$ $\mathrm{kg} \cdot \mathrm{ha}^{-1} \mathrm{~N}$ and $39.6 \mathrm{~kg} \cdot \mathrm{ha}^{-1} \mathrm{~K}$ ) at both locations. At the time of germination (16 June 2014), an additional slow-release fertilizer, was applied at $24.4 \mathrm{~kg} \cdot \mathrm{ha}^{-1} \mathrm{~N}\left(2.2 \mathrm{~kg} \cdot \mathrm{ha}^{-1} \mathrm{P}\right.$ and $\left.12.2 \mathrm{~kg} \cdot \mathrm{ha}^{-1} \mathrm{~K}\right)$ using Sustane $(15 \mathrm{~N}-$ $1.3 \mathrm{P}-7.5 \mathrm{~K})$. Due to excessive yellowing of grass blades in late spring at the SPRF location, we applied a slow-release fertilizer, Sustane $(18 \mathrm{~N}-0.44 \mathrm{P}-8.3 \mathrm{~K})$, at a rate of 201 $\mathrm{kg} \cdot \mathrm{ha}^{-1} \mathrm{~N}\left(5 \mathrm{~kg} \cdot \mathrm{ha}^{-1} \mathrm{P}\right.$ and $\left.93 \mathrm{~kg} \cdot \mathrm{ha}^{-1} \mathrm{~K}\right)$ in July of 2014. In the following year, we again applied the same fertilizer treatment but at the rate of $43.6 \mathrm{~kg} \cdot \mathrm{ha}^{-1} \mathrm{~N}\left(1.1 \mathrm{~kg} \cdot \mathrm{ha}^{-1} \mathrm{P}\right.$ and $20 \mathrm{~kg} \cdot \mathrm{ha}^{-1} \mathrm{~K}$ ). The SPRF location also was provided supplemental irrigation when dry conditions persisted and had a total of 17.8 $\mathrm{cm}$ and $22.2 \mathrm{~cm}$ of water applied in 2014 and 2015 , respectively. No irrigation was provided in 2016. These additional inputs into the SPRF represent actions homeowners would and do take to establish turfgrass in challenging environments such as sandy soil. Plots were neither irrigated nor fertilized at either location in 2016.

Mowing height treatments. Blocks of plants in each replicate were assigned to two commonly used mowing heights in home lawns, with either a $6-\mathrm{cm}$ (low mowing height) or 9-cm (high mowing height) treatment for the course of the study. In 2014 and 2015, mowing height treatments were maintained using a height-based criterion to initiate a mowing event, which proceeded as follows: 1) the height of the tallest vegetation in each monospecies plot was measured; 2) if any plot height exceeded its assigned height for its block by more than one-third $(9.5 \mathrm{~cm}$ for the $6-\mathrm{cm}$ treatment group and $11 \mathrm{~cm}$ for the $9-\mathrm{cm}$ treatment group), all plots in that block were mowed their assigned treatment height. This scheme is based on the botanical principle in which no more than one-third of turf canopy should be pruned at a given time (Turgeon, 1999). Plot heights were surveyed frequently, from every 4 to $7 \mathrm{~d}$ based on growing conditions. This mowing scheme resulted in a fairly conservative mowing schedule that ranged between 3 and 4 and 5 and 7 mowing events per growing season for the SPRF and TROE locations, respectively. Our mowing scheme allowed for mowing treatments to be mowed at different frequencies (i.e., if mowing height effected growth rate), but both treatments grew at relatively the same rate and were mowed together. The SPRF location received fewer mowing treatments because of slower growth rates, presumably due to nutrient and water limitations imposed by the low organic matter content and the high proportions of sand in the soil.

In 2016, plots were mowed on a timed schedule due to logistical constraints. Each site was mowed approximately once per 
Table 1. List of forb species used and their properties extracted from online databases.

\begin{tabular}{llcll}
\hline Species & Common name & Ht $(\mathrm{cm})$ & Habitat & Bloom time \\
\hline Anemone patens (L.) Mill. & Pasque flower & $7.6-45.7$ & Dry-sunny & April-May \\
Claytonia virginica L. & Spring beauty & $7.6-12.7$ & Moist-shady & April-June \\
Oxytropis lambertii Pursh & Purple locoweed & $10.2-40.6$ & Dry-sunny & April-June \\
Astragalus crassicarpus Nutt. & Ground plum & $10.2-61$ & Dry-sunny & May-June \\
Erigeron compositus Pursh & Cutleaf daisy & 15.2 & Dry-sunny & May-July \\
Trifolium repens L. & Dutch white clover & 20.3 & Moist-sunny & June-October \\
$\begin{array}{l}\text { Prunella } \text { vulgaris } \text { ssp. } \\
\quad \text { lanceolata } \text { (W. Bartram) Hultén }\end{array}$ & Lanceleaf selfheal & $7.6-30.5$ & Moist-sunny & June-August \\
Thymus serpyllum L. & Creeping thyme & 20.32 & Dry-sunny & July-September \\
\hline
\end{tabular}

Table 2. Type III analysis of variance results from the linear mixed-effects model for each forb's leafing and flowering units with interactions.

\begin{tabular}{|c|c|c|c|}
\hline Factor & $\begin{array}{l}\text { Degrees of } \\
\text { freedom }\end{array}$ & $\chi^{2}$ & $P$ value \\
\hline \multicolumn{4}{|l|}{ Trifolium repens } \\
\hline \multicolumn{4}{|l|}{ Trifoliate leaves: } \\
\hline Mowing height & 1 & 0.16 & 0.68 \\
\hline Location & 1 & 4.38 & $0.036^{z}$ \\
\hline Mowing height $\times$ Location & 1 & 0.5 & 0.48 \\
\hline \multicolumn{4}{|l|}{ Blooms: } \\
\hline Location & 1 & 0.25 & 0.6 \\
\hline Mowing height & 1 & 0.51 & 0.48 \\
\hline Location $\times$ Mowing height & 1 & 1.1 & 0.31 \\
\hline \multicolumn{4}{|l|}{ Prunella vulgaris } \\
\hline \multicolumn{4}{|l|}{ Basal rosettes: } \\
\hline Mowing height & 1 & 0.16 & 0.68 \\
\hline Location & 1 & 44 & $<0.001^{\mathrm{z}}$ \\
\hline Mowing height $\times$ Location & 1 & 0.1 & 0.78 \\
\hline \multicolumn{4}{|c|}{$\begin{array}{l}\text { Blooms at Turf Research, Outreach, } \\
\text { and Extension center: }\end{array}$} \\
\hline Year & 2 & 10.4 & $<0.001^{\mathrm{z}}$ \\
\hline Mowing height & 1 & 6.3 & $0.01^{\mathrm{z}}$ \\
\hline Year $\times$ Mowing height & 2 & 2.3 & 0.33 \\
\hline \multicolumn{4}{|c|}{ Blooms at Sand Plains Research Farm: } \\
\hline Mowing height & 1 & 2.5 & 0.12 \\
\hline \multicolumn{4}{|l|}{ Thymus serpyllum } \\
\hline \multicolumn{4}{|l|}{ Stems: } \\
\hline Mowing height & 1 & 1.8 & 0.2 \\
\hline Location & 1 & 6.1 & $0.01^{\mathrm{z}}$ \\
\hline Mowing height $\times$ Location & 1 & 1.9 & 0.17 \\
\hline \multicolumn{4}{|l|}{ Blooms 2016: } \\
\hline Mowing height & 1 & 0.46 & 0.5 \\
\hline \multicolumn{4}{|l|}{ Astragalus crassicarpus } \\
\hline \multicolumn{4}{|l|}{ Stems: } \\
\hline Mowing height & 1 & 0.01 & 0.9 \\
\hline
\end{tabular}

${ }^{\mathrm{z} D e n o t e s ~ s i g n i f i c a n t ~ r e s u l t . ~}$

month, which resulted in three mowing events at SPRF and two mowing events at TROE. Although the timing of mowing events in 2016 differed from what was seen in 2014 and 2015, the assignment mowing heights to each block (6 cm vs. $9 \mathrm{~cm})$ was consistent for each year of data collection.

Vegetation data collection. To assess establishment, we collected vegetative data from all plots for all species in September of 2014 and 2015. The number of plants establishing in plots can be difficult to determine for species with spreading vegetation, so aboveground vegetative units appropriate for the species were quantified on the premise it would correlate to the number of individuals establishing in a plot. This method has been most commonly applied for $T$. repens in the form of trifoliate leaves (McCurdy et al., 2013; Sparks et al., 2015), and was adopted here for additional species. Vegetative units were considered any structure that arose from the ground and could be reasonably counted over the entire plot. In addition to trifoliate leaves, these structures included basal rosettes ( $P$. vulgaris) and stems ( $T$. serpyllum and $A$. crassicarpus). These data were collected before a final mowing event in September to avoid introducing a cutting bias in the data. Vegetative structures were not quantified in 2016 because of limited resources.

Bloom data collection. Because each species in this study has a different flowering phenology, plots were surveyed for the onset of flowering every 4 to $7 \mathrm{~d}$, concurrently with plot height measurements. If flowering was detected for any species, blooms within a plot were counted for all plots of that species at that location before mowing. This resulted in a quantification of blooms every 4 to $7 \mathrm{~d}$ once flowering began and until flowering had ceased. Data for each forb species was considered separately during analysis, and only once blooming had begun at that location. A bloom was counted only if it contained at least one unsenesced floret.

In 2016, bloom data were collected differently, with plots receiving overall less management. The first data collection point at SPRF occurred in May to measure the bloom of $A$. crassicarpus, a species that was able to establish only under the sandy soil conditions at SPRF. After this collection point, blooms were measured once per month at each location culminating in a final data collection in late July/early August. Data collection ended in early August based on the phenology of the flowers established in the plots.

Analysis. All analyses were conducted in the R statistical environment ( $\mathrm{R}$ Core Team, 2019). First, a mixed-effects model was specified using the "nlme" package (Pinheiro et al., 2018) with either vegetative units or blooms for each species as a response variable and location $\times$ treatment as a fixed effect. Plot number was specified as a random effect to account for repeated measures of plots over the growing season (in the case of blooms) and year. Model assumptions of homoscedasticity and normality were evaluated by inspection of residual plots. If assumptions were violated, square root transformations were applied and residual plots reevaluated. If assumptions were still not met through square root transformations, a $\log$ transformation was applied and residual plots were reevaluated. In all cases, transformations were sufficient to accommodate model assumptions. All figures represent the untransformed data. We then specified a type III analysis of variance (ANOVA) using the "car" package (Fox and Weisberg, 2011) for each mixed-effects model to determine if fixed effects and their interaction were significant. Analyses were conducted only for species with sufficient data across locations and/or treatments. Although our model accounted for variation through time, we chose to use year as a fixed effect for blooms of $P$. vulgaris. We did this because it was one of the few species we had bloom data for in all 3 years for a location, and also to highlight a significant trend over time for this species. We also evaluated bloom for $P$. vulgaris separately for both locations, as the TROE location had 3 years of bloom data, whereas SPRF achieved bloom only in the final year.

In cases in which there were significant effects were found, a "Tukey" means separation protocol for pairwise comparisons using the "multcomp" package (Hothorn et al., 2008) was used to assess differences between treatments or locations.

\section{Results}

Forb establishment. Of the eight species investigated in our trials, we saw establishment and bloom for four species: $T$. repens, $P$. vulgaris, $T$. serpyllum, and $A$. crassicarpus. Both T. repens and $P$. vulgaris bloomed 


\section{A.) Trifolium repens}

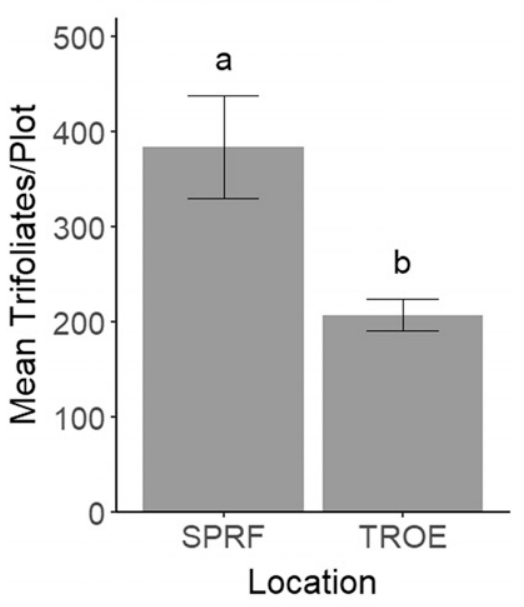

B.) Prunella vulgaris

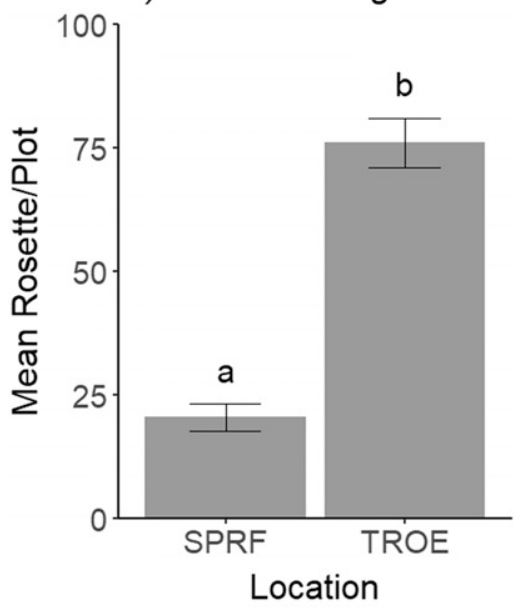

C.) Thymus serpyllum

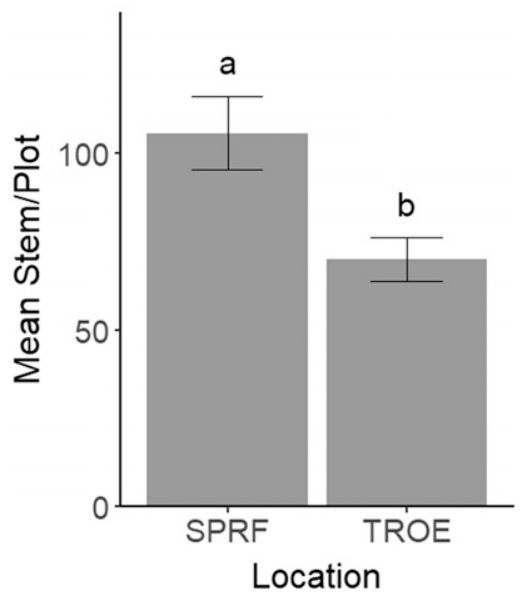

Fig. 1. Number of mean vegetative structures per plot for Trifolium repens (A), Prunella vulgaris (B), and Thymus serpyllum (C) at the location with fine-textured soil and high organic matter (TROE) and the site with high sand content in soil and low organic matter (SPRF). Error bars represent standard error of the mean and letters denote a significant difference as determined by Tukey's mean comparison with an $\alpha=0.05$. during the first growing season, with $T$. serpyllum achieving bloom at both sites by the third year. Although A. crassicarpus established only at the SPRF location, it achieved bloom in some plots by the third year as well. We saw no evidence of vegetative establishment or blooms of the remaining four species: Claytonia virginica, Anemone patens, Oxytropis lambertii, or Erigeron compositus.

Vegetation response to mowing height and location. Results from ANOVA of mixed-effects models indicated that none of the observed forb vegetation showed a significant interaction between mowing treatment and location, or between mowing treatments within location, indicating that mowing did not seem to affect the growth/ development of vegetative structures of forb species we observed (Table 2).

Location, however, was significant for three of the observed forbs. Trifoliate leaf counts of $T$. repens were significantly higher at SPRF (385 mean trifoliates per plot) compared with the TROE location (208 mean trifoliates per plot) (Fig. 1A). The reverse was true for counts of $P$. vulgaris basal rosettes, which were significantly higher at TROE (76 mean rosettes per plot) compared with the SPRF location (20 mean rosettes per plot) (Fig. 2B). Similar to $T$. repens, $T$. serpyllum had significantly higher vegetative growth at the SPRF with 105.8 mean stems per plot compared with TROE with 70 mean stems per plot (Fig. 1C). Leafing units of $A$. crassicarpus were found only at the SPRF location (3.25 mean stems per plot), and were not significantly different between mowing height treatments (Table 2).

Bloom response to mowing height and location. Of the four species found blooming in our trials, $T$. repens was the only species to bloom at both locations in every year. Analysis indicated there were no differences in mean blooms per plot in either location or mowing treatment (Table 2). P. vulgaris blooms were found only at the TROE site in 2014 and 2015, but were found at both sites in 2016. As such, we analyzed these data separately for both TROE and SPRF due to unequal sampling across years. We found a significant effect of mowing height at the TROE location $\left[\mathrm{F}_{(1,18)}=6.2, P=0.02\right]$ with low mowing heights having lower mean rosettes per plot (4.6 mean blooms per plot, $P=0.01)$ than in high mowing height plots (10.6 mean blooms per plot, Fig. 2A). Because of a noticeable decline in $P$. vulgaris blooms after the first year, we tested for a mowing height $\times$ year interaction at the TROE location. We found a significant effect of year $\left[\mathrm{F}_{(2,26)}=10.4, P \leq 0.001\right]$, but we found no evidence of an interaction $\left[\mathrm{F}_{(2,26)}=\right.$ $1.1, P=0.34]$. Means comparisons for blooms over years revealed an initial burst of flowering in 2014, averaging 17.4 mean blooms per plot, followed by a steep decline in 2015 that was sustained in 2016 (averaging 5.8 and 4.4 mean blooms per plot, respectively, Fig. 3). This initial bloom was significantly higher than in both 2015 and 2016
( $P \leq 0.01$ for both years), but 2015 and 2016 did not differ from each other $(P=0.7)$.

T. serpyllum blooms were found only at the SPRF location in 2015 in 3 of 10 plots during the course of its bloom season, and only in plots mowed at the $9-\mathrm{cm}$ mowing height. As a result, means comparisons for location and mowing height were not appropriate. Conversely, in 2016, the TROE location had a significant amount of $T$. serpyllum bloom (every plot had blooms), whereas the SPRF location had only a single plot with blooms. Because of the negligible bloom at SPRF, mowing height comparisons for this species were done only for the TROE location. Bloom counts were 10.6 per plot in the high mowing height treatment compared with four per plot in the low mowing height treatment; this relationship was not significant $\left[\mathrm{F}_{(1,8)}=0.5, P=0.54\right.$, Fig. $\left.2 \mathrm{~B}\right]$.

Two A. crassicarpus blooms were observed in one plot at the SPRF location in 2015, and in 2016 three plots at SPRF were found to have blooms, with 2,12 , and 25 blooms for each plot. The small number of plots in which blooms occurred made statistical analysis inappropriate, but these results show that this species has the potential to establish and bloom in lawns, if only sporadically.

\section{Discussion}

This study represents an important first step in identifying forbs and management practices that could be applied in the diversification of lawns for the purpose of pollinator conservation. Of the eight forbs we investigated, four of them established and bloomed, with location and mowing height treatments playing a mixed role for each species.

Location played a prominent role in the vegetative establishment of all species observed, with $T$. repens, $P$. vulgaris, $T$. serpyllum, and A. crassicarpus all showing differences in vegetative growth between locations. The location with high soil sand content (SPRF) favored T. repens, T. serpyllum, and A. crassicarpus. T. repens established well at both sites and is well known for its adaption to a wide range of soil conditions (Turkington and Burdon, 1983). Its increased vegetative growth at the SPRF may be due to nitrogen limitation (as evidenced by yellowing of grass leaves) imparting a competitive advantage for the species over its companion grass due to the ability of $T$. repens to fix nitrogen. To our knowledge, no studies on the optimal establishment and site conditions for $P$. vulgaris or $T$. serpyllum have been conducted, although reports of optimal growing conditions exist. The U.S. Natural Resource Conservation Service reports that $P$. vulgaris prefers moist and disturbed conditions across a wide range of habitats (Young-Mathews, 2012), suggesting that the low moisture retention of sandy soils may not favor its growth. Studies on the distribution of $T$. serpyllum suggest that it is most commonly found in dry and human disturbed areas, 

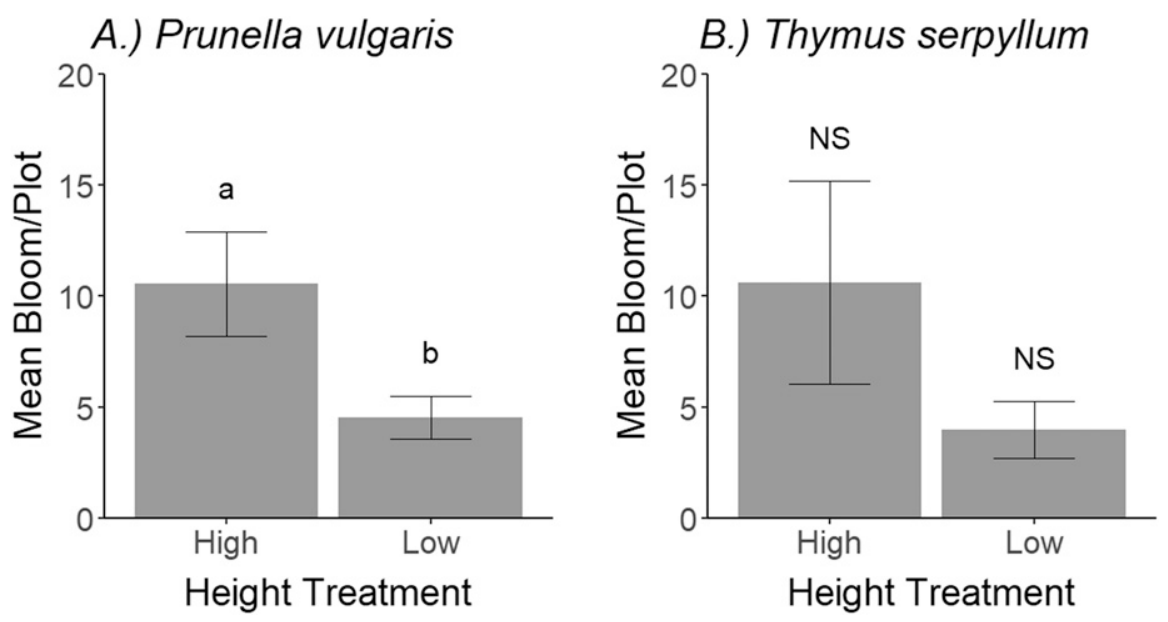

Fig. 2. Number of mean blooms per plot for Prunella vulgaris (A) and Thymus serpyllum (B) in treatments with a higher mowing regimen $(9 \mathrm{~cm})$ and the lower mowing regimen $(6 \mathrm{~cm})$. Error bars represent standard error of the mean and letters denote a significant difference as determined by Tukey's mean comparison with an $\alpha=0.05$.

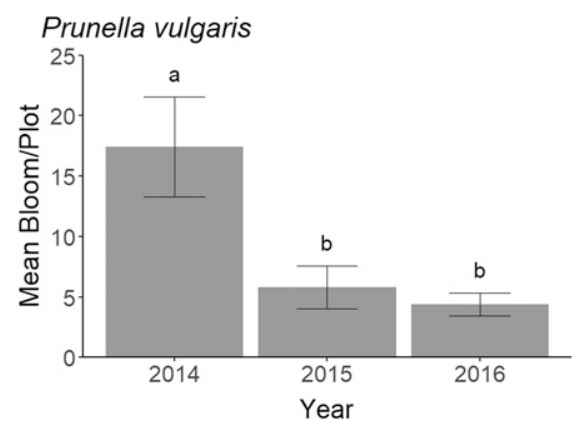

Fig. 3. Number of mean blooms per plot for Prunella vulgaris in the 3 years of floral data collection at the TROE site. Error bars represent standard error of the mean and letters denote a significant difference as determined by Tukey's mean comparison with an $\alpha=0.05$.

although it can tolerate mesic conditions as well (Eriksson, 1998). This preference for drier conditions may have played a part in its success at the SPRF location.

Location also affected the bloom of some species. $P$. vulgaris blooming was delayed at the SPRF until 2016, and then achieved only a relatively low level of one mean bloom per plot compared with the TROE location, which achieved 7.6 mean blooms per plot in the same year. T. serpyllum achieved its highest level of bloom in 2016 at TROE, counter to the 201415 trend for higher stem counts at the SPRF. Because we ceased any supplemental inputs (such as water and nutrients) at the SPRF location that year, it is difficult to determine if the SPRF location became less favorable during this time, or if the TROE location establishment was delayed. From other studies we have conducted with $T$. serpyllum, we have observed that, although $T$. serpyllum seems slow to establish, it does well in mesic lawn environments, such as at TROE. This is also supported by other observations of lawn environments (Eriksson, 1998; Stalter et al., 1993).

Mowing height had a negligible role on vegetative establishment at both sites and had no impact on the flowering of observed species except for a consistent negative effect on $P$. vulgaris in the low mowing height treatment at TROE. This is somewhat supported by previous work that investigated mowing frequency effects on turfless lawn, where $P$. vulgaris coverage was affected by mowing frequency (Smith and Fellowes, 2014). The lack of negative effect of mowing height was surprising given previous studies finding negative effects of mowing frequency and height on lawn forbs (Bertoncini et al., 2012; Garbuzov et al., 2014; Lerman et al., 2018). One possible explanation is due to the relatively low frequency with which our cutting treatments were applied. Because we used a height-based mowing criterion combined with the slow-growing grass $F$. brevipilla, the number of mowing events was much lower compared with other studies. suggest combining slow-growing turfgrass with height-based mowing regimens reduces mowing pressure on turf swards and thus the potential negative effects of mowing on forbs. Previous research has shown that turf species can affect forb flowering (Lane et al., 2019), regardless of mowing regimen, and is an important consideration in crafting floral lawns. Regardless of low mowing frequency, $P$. vulgaris still saw negative impacts on bloom at the low mowing height, highlighting that some species may be more sensitive than others to mowing regimen during bloom.

Four of the eight species, $C$. virginica, $A$. patens, O. lambertii, and E. compositus, did not establish in our research plots. Their failure to establish in plots could be for a number of reasons, such as germination challenges and environmental mismatches. When we conducted germination tests in a growth chamber for the selected species, the nonestablishing species either did not germinate at all (E. compositus) or only sparsely (C. virginica, $A$. patens, O. lambertii) (S2). This lack of germination indicates that there may be additional dormancy mechanisms, This is somewhat encouraging, as our results germination requirements, or planting strategies needed beyond cold stratification. $C$. virginica, for example, has been known to establish in lawns (Schemske et al., 1978), but is typically found in more shaded environments where its seeds are stored underground by ants. This may indicate an important biotic interaction our research plots were unable to re-create. A. patens also has been found in association with close grazing and mowing (Wildeman and Steeves, 1982), but previously documented low germination rates (Greene and Curtis, 1950) indicate other dormancy breaking requirements may have been poorly met by our study design. These challenges could be overcome through additional seed treatments, or transplanting individuals directly into lawns. Previous work has seen some success in the transplanting of $C$. virginica, and other species, directly into warm-season lawns (Wisdom, 2018).

Another possible explanation for why these species failed to establish is that our growing sites were poor matches for their environmental needs. O. lambertii is a lowgrowing forb but is more characteristic in dry environments (Wheeler et al., 1992; Whitman and Stevens, 1952). E. compositus, although a native to the central United States, is more characteristic of rocky sites in montane habitats very different from our planting sites. We believed that the low growth habit and a well-drained soil (such as at SPRF) would allow these species to germinate and persist given the slow-growing turf companion species, but the increased inputs and mowing may have excluded them.

Overall, these results are encouraging and indicate that forbs can establish and bloom, especially $T$. repens, $P$. vulgaris, $T$. serpyllum, and $A$. crassicarpus, when seeded concurrently with $F$. brevipilla. Future efforts to diversify lawns would benefit from expanded species exploration using both seed and transplanted individuals. One of the largest barriers to implementing flowering lawns with native forbs is a lack of seed stock available from local nurseries. Many native plants have low-growing traits that are desirable for forbs in turfgrass plantings, such as low and competitive growth habits, but seeds are not available in appreciable quantities. This lack of seed stock is potentially due to the difficulty in harvesting plant seeds from low-growing plants, as well as a lack of demand from the public for plants with these qualities. Future directions with flowering lawns using native plants should seek partners in the native plant seed industry to facilitate the exploration and production of candidate plant seeds for use in research and by the public.

\section{Literature Cited}

Bertoncini, A.P., N. Machon, S. Pavoine, and A. Muratet. 2012. Local gardening practices shape urban lawn floristic communities. Landsc. Urban Plan. 105:53-61.

Bigelow, D.P. and A. Borchers. 2017. Major uses of land in the United States, 2012, p. 62. U.S. 
Dept. Agr. Economic Res. Serv. Economic Information Bul. 178

Blaauw, B.R. and R. Isaacs. 2014. Flower plantings increase wild bee abundance and the pollination services provided to a pollinationdependent crop. J. Appl. Ecol. 51:890-898.

Braaker, S., J. Ghazoul, M.K. Obrist, and M. Moretti. 2014. Habitat connectivity shapes urban arthropod communities: the key role of green roofs. Ecology 95:1010-1021.

Eriksson, А. 1998. Regional distribution of Thymus serpyllum: Management history and dispersal limitation. Ecography 21:35-43.

Fox, J. and S. Weisberg. 2011. An R companion to applied regression. 2nd ed. Sage Publishing, Thousand Oaks, CA.

Frankie, G.W., R.W. Thorp, M. Schindler, B. Ertter, and M. Rizzardi. 2005. Ecological patterns of bees and their host ornamental flowers in two northern California cities. J. Kans. Entomol. Soc. 78:227-246.

Garbuzov, M., K.A. Fensome, and F.L.W. Ratnieks. 2014. Public approval plus more wildlife: Twin benefits of reduced mowing of amenity grass in a suburban public park in Saltdean, UK. Insect Conserv. Divers. 8:107-119.

Goddard, M.A., A.J. Dougill, and T.G. Benton. 2010. Scaling up from gardens: Biodiversity conservation in urban environments. Trends Ecol. Evol. 25:90-98.

Goulson, D., E. Nicholls, C. Botias, and E.L. Rotheray. 2015. Bee declines driven by combined stress from parasites, pesticides, and lack of flowers. Science 347, doi: 10.1126/science. 1255957.

Greene, H.C. and J.T. Curtis. 1950. Germination studies of Wisconsin prairie plants. Amer. Midland Naturalist 43:186-194.

Grubb, P.J. 1977. The maintenance of speciesrichness in plant communities: The importance of the regeneration niche. Biol. Rev. Cambridge Philosophical Soc. 52:107-145.

Hopwood, J., L. Winkler, B. Deal, and M. Chivvis. 2010. Use of roadside prairie plantings by native bees, Living Roadway Trust Report.

Hothorn, T., F. Bretz, and P. Westfall. 2008. Simultaneous inference in general parametric models. Biometrical J. 50:346-363.

Lane, I., E. Watkins, and M. Spivak. 2019. Turfgrass species affect the establishment and bloom of Kura clover (Trifolium ambiguum) in lawns. HortScience 54:824-828.

Larson, J.L., A.J. Kesheimer, and D.A. Potter. 2014. Pollinator assemblages on dandelions and white clover in urban and suburban lawns. J. Insect Conservation 18:863-873.

Leffel, R.C. and P.B. Gibson. 1973. White clover, p. 167-176. In: Forages: The science of grassland agriculture.

Lerman, S.B., A.R. Contosta, J. Milam, and C. Bang. 2018. To mow or to mow less: Lawn mowing frequency affects bee abundance and diversity in suburban yards. Biol. Conservation 221:160-174.

Lerman, S.B. and J. Milam. 2016. Bee fauna and floral abundance within lawn-dominated suburban yards in Springfield, MA. Ann. Entomol. Soc. Am. 109:713-723.

Losey, J.E. and M. Vaughan. 2006. The economic value of ecological services provided by insects. Bioscience 56:311-323.

McCurdy, J.D., J.S. McElroy, E.A. Guertal, and F. Hall. 2013. White clover (Trifolium repens) establishment within dormant bermudagrass turf: Cultural considerations, establishment timing, seeding rate, and cool-season companion grass species. HortScience 48:1556-1561.

McKinney, M.L. 2002. Urbanization, biodiversity, and conservation. Bioscience 52:883-890.

Milesi, C., S.W. Running, C.D. Elvidge, J.B. Dietz, B.T. Tuttle, and R.R. Nemani. 2005. Mapping and modeling the biogeochemical cycling of turf grasses in the United States. Environ. Manage. 36:426-38.

Morandin, L.A. and C. Kremen. 2013. Hedgerow restoration promotes pollinator populations and exports native bees to adjacent fields. Ecol. Appl. 23:829-839.

Murray, T.E., M. Kuhlmann, and S.G. Potts. 2009. Conservation ecology of bees: Populations, species and communities. Apidologie 40:211-236.

Noordijk, J., K. Delille, A.P. Schaffers, and K.V. Sýkora. 2009. Optimizing grassland management for flower-visiting insects in roadside verges. Biol. Conserv. 142:2097-2103.

Ollerton, J., R. Winfree, and S. Tarrant. 2011. How many flowering plants are pollinated by animals? Oikos 120:321-326.

Pardee, G.L. and S.M. Philpott. 2014. Native plants are the bee's knees: Local and landscape predictors of bee richness and abundance in backyard gardens. Urban Ecosyst. 17:641-659.

Pawelek, J.C., G.W. Frankie, R.W. Thorp, and M. Przybylski. 2009. Modification of a community garden to attract native bee pollinators in urban San Luis Obispo, California. Cities Environ. 2:1-20.

Pinheiro, J., D. Bates, S. DebRoy, D. Sarkar, and R.C. Team. 2018. nlme: Linear and nonlinear mixed effects models. R package version 3.1-137.

Rader, R., I. Bartomeus, L.A. Garibaldi, M.P.D. Garratt, B.G. Howlett, R. Winfree, S.A. Cunningham, M.M. Mayfield, A.D. Arthur, G.K.S. Andersson, R. Bommarco, C. Brittain, L.G. Carvalheiro, N.P. Chacoff, M.H. Entling, B. Foully, B.M. Freitas, B. Gemmill-Herren, J. Ghazoul, S.R. Griffin, C.L. Gross, L. Herbertsson, F. Herzog, J. Hipólito, S. Jaggar, F. Jauker, A.M. Klein, D. Kleijn, S. Krishnan, C.Q. Lemos, S.A.M. Lindström, Y. Mandelik, V.M. Monteiro, W. Nelson, L. Nilsson, D.E. Pattemore, N.O. Pereira, G. Pisanty, S.G. Potts, M. Reemer, M. Rundlöf, C.S. Sheffield, J. Scheper, C. Schüepp, H.G. Smith, D.A Stanley, J.C. Stout, H. Szentgyörgyi, H. Taki, C.H. Vergara, B.F. Viana, and M. Woyciechowski. 2015. Non-bee insects are important contributors to global crop pollination. Proc. Natl. Acad. Sci. USA 113:146-151.

Rosenzweig, M.L. 2003. Reconciliation ecology and the future of species diversity. Oryx 37 : 194-205.

Schemske, D.W., M.F. Willson, M.N. Melampy, L.J. Miller, L. Verner, K.M. Schemske, and L.B. Best. 1978. Flowering ecology of some spring woodland herbs. Ecology 59:351-366.

Shwartz, A., A. Muratet, L. Simon, and R. Julliard. 2013. Local and management variables outweigh landscape effects in enhancing the diversity of different taxa in a big metropolis. Biol. Conserv. 157:285-292.

Smith, L.S., M.E.J. Broyles, H.K. Larzleer, and M.D.E. Fellowes. 2014. Adding ecological value to the urban lawnscape. Insect abundance and diversity in grass-free lawns. Biodiversity and Conservation 24:47-62.
Smith, L.S. and M.D.E. Fellowes. 2014. The grassfree lawn: Management and species choice for optimum ground cover and plant diversity. Urban For. Urban Green. 13:433-442.

Southwick, E.E. and L.J. Southwick. 1992. Estimating the economic value of honey bees (Hymenoptera: Apidae) as agricultural pollinators in the United States. J. Econ. Entomol. 85:621-633.

Sparks, B., G. Munshaw, D. Williams, M. Barrett, V. Drive, and P. Woosley. 2015. Preplant cultivation techniques and planting date effects on white clover establishment into an existing cool-season turfgrass sward. HortScience 50:615-620.

Stalter, R., P. Lynch, and J. Schaberl. 1993. Vascular flora of Saratoga National Historical Park, New York. Bull. Torrey Bot. Club 120: 166-176.

R Core Team. 2019. R: A language and environment for statistical computing. R Foundation for Statistical Computing, Vienna, Austria.

Thompson, K., J.G. Hodgson, R.M. Smith, P.H Warren, and K.J. Gaston. 2004. Urban domestic gardens (III): Composition and diversity of lawn floras. J. Veg. Sci. 15:373-378.

Turgeon, A.J. 1999. Turfgrass management. 5 th ed. Prentice Hall, Upper Saddle River, NJ.

Turkington, R. and J.J. Burdon. 1983. The biology of Canadian weeds. 57. Trifolium repens L. Can. J. Plant Sci. 63:243-266.

United Nations, Department of Economic and Social Affairs, Population Division. 2018. World urbanization prospects: The 2014 Revision, Highlights. 30 Oct. 2019. <https://population.un.org/ wup/Publications/Files/WUP2018-Highlights. pdf $>$.

Wheeler, G.A., E.J. Cushing, E. Gorham, T. Morley, and G.B. Ownbey. 1992. A major floristic boundary in Minnesota: An analysis of 280 taxa occurring in the western and southern portions of the state. Can. J. Bot. 70:319-333.

Wheeler, M.M., C. Neill, P.M. Groffman, M. Avolio, N. Bettez, J. Cavender-Bares, R. Chowdhury, L. Darling, J.M. Grove, S.J. Hall, J.B. Heffernan, S.E. Hobbie, K.L. Larson, J.L. Morse, K.C. Nelson, L.A. Ogden, J. O’NeilDunne, D.E. Pataki, C. Polsky, M. Steele, and T.L.E. Trammell. 2017. Continental-scale homogenization of residential lawn plant communities. Landscape and Urban Planning 165: 54-63.

Whitman, W.C. and O.A. Stevens. 1952. Native legumes of North Dakota grassland. Proc. North Dakota Acad. Sci. 6:73-78.

Whitney, G.G. 1985. A quantitative analysis of the flora and plant communities of a representative midwestern U.S. town. Urban Ecol. 9:143-160.

Wildeman, A.G. and T.A. Steeves. 1982. The morphology and growth cycle of Anemone patens. Can. J. Bot. 60(7):1126-1137.

Wilson, J.S., M.L. Forister, and O.M. Carril. 2017. Interest exceeds understanding in public support of bee conservation. Frontiers Ecol. Environ. 15:460-466

Wisdom, M. 2018. Systems to attract and feed pollinators in warm-season lawns. Theses and Dissertations. 2975. <https://scholarworks.uark. edu/etd/2975>.

Young-Mathews, A. 2012. Plant fact sheet for lance selfheal (Prunella vulgaris ssp. lanceolata). USDA Natural Resources Conservation Service, Corvallis Plant Materials Center, Corvallis, OR. 
Supplemental Table 1. Soil fertility and texture results from the Turf Research, Outreach, and Extension Center (TROE) and the Sand Plains Research Farm (SPRF).

\begin{tabular}{|c|c|c|c|c|c|c|c|}
\hline Name & Bray P (ppm) & $\mathrm{NH}_{4} \mathrm{OAc}-\mathrm{K}(\mathrm{ppm})$ & Organic matter $(\%)$ & Water $\mathrm{pH}$ & Sand (\%) & Silt (\%) & Clay (\%) \\
\hline TROE & 61 & 149 & 4.3 & 6.1 & 7.4 & 61.3 & 31.3 \\
\hline SPRF & 39 & 53 & 1.7 & 6.6 & 68.8 & 8.7 & 22.5 \\
\hline
\end{tabular}

Supplemental Table 2. Mean temperature and precipitation for each month of the growing season, at the Turf Research, Outreach, and Extension center (TROE) and the Sand Plains Research Farm (SPRF).

\begin{tabular}{|c|c|c|c|c|}
\hline$\overline{\text { Month }}$ & Location & $\mathrm{Yr}$ & Mean temp $\left({ }^{\circ} \mathrm{C}\right)$ & Mean precipitation $(\mathrm{cm})$ \\
\hline April & SPRF & 2014 & 4.5 & 13.97 \\
\hline April & SPRF & 2015 & 8.4 & 4.7 \\
\hline April & SPRF & 2016 & 7.3 & 5 \\
\hline April & TROE & 2014 & 4.6 & 17.6 \\
\hline April & TROE & 2015 & 8.5 & 5.3 \\
\hline April & TROE & 2016 & 7.7 & 9.3 \\
\hline May & SPRF & 2014 & 13.6 & 22 \\
\hline May & SPRF & 2015 & 13.6 & 14.5 \\
\hline May & SPRF & 2016 & 14.3 & 6.7 \\
\hline May & TROE & 2014 & 13.8 & 9 \\
\hline May & TROE & 2015 & 13.8 & 12.5 \\
\hline May & TROE & 2016 & 14.8 & 5.2 \\
\hline June & SPRF & 2014 & 19.1 & 21.6 \\
\hline June & SPRF & 2015 & 18.9 & 8.7 \\
\hline June & SPRF & 2016 & 19.3 & 6.4 \\
\hline June & TROE & 2014 & 21.1 & 23.4 \\
\hline June & TROE & 2015 & 19.8 & 8.4 \\
\hline June & TROE & 2016 & 20.4 & 9.3 \\
\hline July & SPRF & 2014 & 19.9 & 5.3 \\
\hline July & SPRF & 2015 & 21.1 & 18.6 \\
\hline July & SPRF & 2016 & 21 & 16.5 \\
\hline July & TROE & 2014 & 21.8 & 6.9 \\
\hline July & TROE & 2015 & 21.9 & 15.7 \\
\hline July & TROE & 2016 & 22.5 & 15.2 \\
\hline August & SPRF & 2014 & 20.3 & 10.6 \\
\hline August & SPRF & 2015 & 19.5 & 14.8 \\
\hline August & SPRF & 2016 & 20.6 & 11.7 \\
\hline August & TROE & 2014 & 22.2 & 7.9 \\
\hline August & TROE & 2015 & 20.1 & 7.1 \\
\hline August & TROE & 2016 & 21.4 & 25.1 \\
\hline September & SPRF & 2014 & 15.4 & 9.8 \\
\hline September & SPRF & 2015 & 18.2 & 4.1 \\
\hline September & SPRF & 2016 & 16.4 & 12.9 \\
\hline September & TROE & 2014 & 16.1 & 5.6 \\
\hline September & TROE & 2015 & 18.8 & 9.7 \\
\hline September & TROE & 2016 & 17.5 & 13.2 \\
\hline
\end{tabular}

Supplemental Table 3. Seed germination testing seeds for each species were separated into three replicates of 30 seeds. Seeds were subjected to $60 \mathrm{~d}$ of $1.5^{\circ} \mathrm{C}$ for cold stratification, then placed in a growth chamber in petri dishes with germination paper. Petri dishes were checked daily to ensure adequate moisture. After 14 d, initial germination was checked (7 Nov.), and germination was recorded. Germinated seeds were removed, and remaining seeds were checked on 25 Nov. Data were averaged for each species.

\begin{tabular}{lc}
\hline Species & Germination (\%) \\
\hline Trifolium repens & 89 \\
Thymus serpyllum & 61 \\
Anemone patens & 2 \\
Prunella vulgaris & 72 \\
Erigeron compositus & 0 \\
Astragalus crassicarpus & 4 \\
Oxytropis lambertii & 3 \\
Claytonia virginica & 3 \\
\hline
\end{tabular}

